\title{
Infrared Spectroscopic Characterization of Tellurite Glasses Containing Heavy Metal Oxides
}

\author{
G. Upender, ${ }^{1}$ C. P. Vardhani, ${ }^{1}$ V. Kamalaker, ${ }^{1}$ and V. Chandra Mouli ${ }^{1,2}$ \\ ${ }^{1}$ Glassy Materials Research Laboratory (GMRL), Department of Physics, Osmania University, Hyderabad 500 007, India \\ ${ }^{2}$ Pulla Reddy Institute of Technology, Vargal, Madak, A.P., India \\ Correspondence should be addressed to V. Chandra Mouli, vorucm90@yahoo.com
}

Received 13 July 2009; Revised 28 October 2009; Accepted 15 November 2009

Copyright ( $\odot 2010$ G. Upender et al. This is an open access article distributed under the Creative Commons Attribution License, which permits unrestricted use, distribution, and reproduction in any medium, provided the original work is properly cited.

\begin{abstract}
The infrared (IR) spectra of $(100-\mathrm{x}) \mathrm{TeO}_{2}-\mathrm{xWO}_{3}$ glasses reveal that the glass network consists of $\left[\mathrm{TeO}_{3}\right] /\left[\mathrm{TeO}_{3+1}\right],\left[\mathrm{TeO}_{4}\right]$, $\left[\mathrm{WO}_{4}\right]$, and $\left[\mathrm{WO}_{6}\right]$ groups as basic structural units. Addition of $\mathrm{WO}_{3}$ oxide to the binary $\mathrm{TeO}_{2}-\mathrm{WO}_{3}$ glasses increases the amount of lower coordination of $\left[\mathrm{TeO}_{3}\right] /\left[\mathrm{TeO}_{3+1}\right]$ units and decreases the higher coordination of $\left[\mathrm{TeO}_{4}\right]$ units and also the formation of Te-O-W linkages at the expense of Te-O-Te linkages. The IR spectra of $60 \mathrm{TeO}_{2}-(40-\mathrm{x}) \mathrm{WO}_{3}-\mathrm{xPbO}$ glasses reveal that the glass network consists of $\left[\mathrm{TeO}_{3}\right],\left[\mathrm{TeO}_{4}\right],\left[\mathrm{WO}_{4}\right],\left[\mathrm{WO}_{6}\right]$, and $\left[\mathrm{PbO}_{4}\right]$ units. Changes in the coordination state of tellurium and tungsten ions occur when the $\mathrm{PbO}$ and $\mathrm{WO}_{3}$ concentrations are varied. The dual role of the lead ions is confirmed in $60 \mathrm{TeO}_{2}-(40-\mathrm{x}) \mathrm{WO}_{3}-\mathrm{xPbO}$ glass system. The $\mathrm{W}$ ion coordination state changes from 4 to 6 when $\mathrm{WO}_{3}$ concentration increases beyond 30 mol\% in both (100$\mathrm{x}) \mathrm{TeO}_{2}-\mathrm{xWO}_{3}$ and $60 \mathrm{TeO}_{2}-(40-\mathrm{x}) \mathrm{WO}_{3}-\mathrm{xPbO}$ glass systems. The IR spectra of $60 \mathrm{~B}_{2} \mathrm{O}_{3}-10 \mathrm{TeO}_{2}-(30-\mathrm{x}) \mathrm{ZnO}-\mathrm{xPbO}$ glasses reveal that the glass network consists of $\left[\mathrm{TeO}_{3}\right],\left[\mathrm{BO}_{3}\right]$, and $\left[\mathrm{BO}_{4}\right]$ groups.
\end{abstract}

\section{Introduction}

Glasses with heavy metal oxides $\left(\mathrm{TeO}_{2}, \mathrm{GeO}_{2}, \mathrm{Bi}_{2} \mathrm{O}_{3}, \mathrm{WO}_{3}\right.$, $\mathrm{PbO}, \mathrm{Ag}_{2} \mathrm{O}$, etc.) are promising materials for IR technologies, nonlinear optics, and design of laser devices [1]. Telluritebased glasses are the subject of intense current research because of the interesting electrical and optical properties. Main features include extended Infrared transmittance [2], high nonlinear optical indices [3], low fusion temperature, and they constitute an excellent matrix for active element doping, justifying a continuous technological interest [4]. The synthesis of glasses with high refractive index values is of great importance in the glass science and the optical industries. Among tellurite glasses, the glasses based on $\mathrm{WO}_{3}$, $\mathrm{PbO}$, and other heavy-metal oxides (HMO) are known to have high linear refractive indices $(n>2.1)$ [5-7]. The high linear refractive index of $\mathrm{Te}^{+4}$ containing glasses is attributed to the nonbonding lone electron pair $5 s^{2}$ of tellurium [8].

The $\mathrm{PbO}$ is unique in its influence on the glass structure and is widely used in glasses because it enhances the resistance against devitrification, improves the chemical durability, and lowers the melting temperature $[9,10]$. $\mathrm{PbO}$ could act both as glass network former and as modifier depending on its concentration in the glasses $[11,12] . \mathrm{B}_{2} \mathrm{O}_{3}$ is one of the best and well-known glass former. Addition of small amount of $\mathrm{TeO}_{2}$ into the borate glass network enhances the glass quality with an improvement in transparency, refractive index. Addition of $\mathrm{ZnO}$ into the boro-tellurite glass network produces low rates of crystallization and increases the glass-forming ability [13]. Hence it is of interest to study the structural changes brought about by $\mathrm{PbO}$ in tungsto-tellurite and boro-tellurite glasses, which may help in predicting the physico-chemical properties.

The aim of the present work is to study the short range structure and structural changes with compositions of (100x) $\mathrm{TeO}_{2}-\mathrm{xWO}_{3}, 60 \mathrm{TeO}_{2}-(40-\mathrm{x}) \mathrm{WO}_{3}-\mathrm{xPbO}$, and $60 \mathrm{~B}_{2} \mathrm{O}_{3}-$ $10 \mathrm{TeO}_{2}-(30-\mathrm{x}) \mathrm{ZnO}-\mathrm{xPbO}$ glass systems by Infrared spectroscopy.

\section{Experimental}

The tellurium-based glasses $(100-\mathrm{x}) \mathrm{TeO}_{2}-\mathrm{xWO}_{3}, 60 \mathrm{TeO}_{2}-$ $(40-\mathrm{x}) \mathrm{WO}_{3}-\mathrm{xPbO}$, and $60 \mathrm{~B}_{2} \mathrm{O}_{3}-10 \mathrm{TeO}_{2}-(30-\mathrm{x}) \mathrm{ZnO}-\mathrm{xPbO}$ were prepared from $99.9 \%$ purity-grade oxides (Aldrich). Powders of $\mathrm{TeO}_{2}, \mathrm{WO}_{3}, \mathrm{~B}_{2} \mathrm{O}_{3}, \mathrm{ZnO}$, and $\mathrm{PbO}$ were weighted to get the required composition and ground in a mortar 
TABLE 1: Glass compositions.

\begin{tabular}{lccccc}
\hline \multirow{2}{*}{ Samples } & \multicolumn{5}{c}{ Oxides (mol\%) } \\
& $\mathrm{TeO}_{2}$ & $\mathrm{WO}_{3}$ & $\mathrm{PbO}$ & $\mathrm{B}_{2} \mathrm{O}_{3}$ & $\mathrm{ZnO}$ \\
\hline TW1 & 90 & 10 & - & - & - \\
TW2 & 80 & 20 & - & - & - \\
TW3 & 70 & 30 & - & - & - \\
TW4 & 60 & 40 & - & - & - \\
\hline TWP1 & 60 & 40 & 0 & - & - \\
TWP2 & 60 & 30 & 10 & - & - \\
TWP3 & 60 & 20 & 20 & - & - \\
TWP4 & 60 & 10 & 30 & - & - \\
TWP5 & 60 & 0 & 40 & - & - \\
\hline BTZP1 & 10 & - & 0 & 60 & 30 \\
BTZP2 & 10 & - & 10 & 60 & 20 \\
BTZP3 & 10 & - & 20 & 60 & 10 \\
BTZP4 & 10 & - & 30 & 60 & 0 \\
\hline
\end{tabular}

with a pestle for 1 hour to obtain homogeneous mixtures. Each batch was then transferred to a platinum crucible and melted at about $800-950^{\circ} \mathrm{C}$ in an electric furnace. This melt was held at this temperature for 30 minutes until a bubble-free liquid was formed. The melts were stirred to achieve desirable homogeneity. The homogeneous melt was quenched by pouring it on to a preheated stainless steel mould to avoid excess thermal shocks. The glasses were annealed for 8 hours at $100^{\circ} \mathrm{C}$ to relieve the mechanical strains. The compositions of the glass samples employed in the present study are given in Table 1.

X-ray diffractograms of powdered glass samples were recorded using a copper target $\left(\lambda\left(k_{\alpha}\right)=1.54 \mathrm{~A}^{\circ}\right)$ on a Philips PW (1140) diffractometer at room temperature. The IR spectra of the glass samples were recorded at room temperature using a Perkin-Elmer FT-IS spectrometer model 1605 using $\mathrm{KBr}$ disc technique. The investigated samples were ground to fine particles and then mixed with $\mathrm{KBr}$ in the ratio $(0.002: 0.2 \mathrm{~g})$ glass to $\mathrm{KBr}$, respectively. The weighted mixture was then subjected to a pressure of 5 tons $/ \mathrm{cm}^{2}$. The transmission spectra were measured immediately after preparing the desired disks.

\section{Results and Discussion}

3.1. XRD and IR Spectra of (100-x) $\mathrm{TeO}_{2}-x \mathrm{WO}_{3}$ Glasses. The $\mathrm{X}$-ray diffraction spectra show no peaks, indicating that the samples are amorphous.

The IR spectra of $(100-\mathrm{x}) \mathrm{TeO}_{2}-\mathrm{xWO}_{3}$ glass system recorded in the wave number region $1150-440 \mathrm{~cm}^{-1}$ are shown in Figure 1. The IR spectra of these glasses are characterized by IR absorption bands in the wave number regions $925-945 \mathrm{~cm}^{-1}, 850-865 \mathrm{~cm}^{-1}, 730-790 \mathrm{~cm}^{-1}, 600-$ $680 \mathrm{~cm}^{-1}$, and $460-490 \mathrm{~cm}^{-1}$. The IR band positions are summarized in Table 2. The IR absorption in the range $600-680 \mathrm{~cm}^{-1}$ in the tellurium containing glasses is due to stretching vibrations of the $\mathrm{Te}-\mathrm{O}$ bond in the $\mathrm{TeO}_{4}$ tbp (trigonal bipyramids) and $\mathrm{TeO}_{3}$ tp (trigonal pyramids) units [14]. The band observed at $640 \mathrm{~cm}^{-1}$ in $90 \mathrm{TeO}_{2}-10 \mathrm{WO}_{3}$
TABLE 2: Observed IR band positions in the (100-x) $\mathrm{TeO}_{2}-\mathrm{xWO}_{3}$ glass system.

\begin{tabular}{llllrll}
\hline Sample ID & \multicolumn{7}{c}{ IR bands $\left(\mathrm{cm}^{-1}\right)$} \\
\hline TW1 & $460-490$ & 640 & - & 730 & 865 & 925 \\
TW2 & $460-490$ & 645 & - & 735 & 860 & 934 \\
TW3 & $460-490$ & - & 665 & 745 & 855 & 940 \\
TW4 & $460-490$ & - & 675 & 790 & 850 & 945 \\
\hline
\end{tabular}

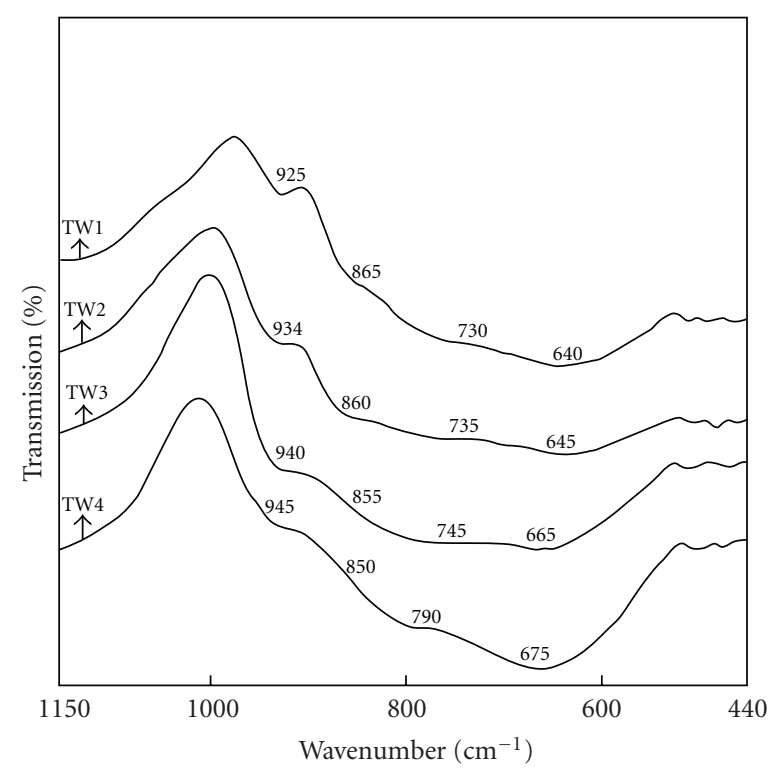

Figure 1: IR spectra of $\mathrm{TeO}_{2}-\mathrm{WO}_{3}$-glasses.

(TW1) glass is assigned to $\mathrm{TeO}_{4}$ tbp units. The band at around $925 \mathrm{~cm}^{-1}$ in TW1 in the high wave number region of the spectrum is characteristic of the presence of the tungsten ions in $\left[\mathrm{WO}_{4}\right]$ units or $\left[\mathrm{WO}_{6}\right]$ units in the structure of the glass [15-17]. The band at around $730-790 \mathrm{~cm}^{-1}$ is due to $\mathrm{Te}-\mathrm{O}_{\text {eq }}$ bond vibrations of distorted $\mathrm{TeO}_{4}$ units $[17,18]$. The shoulder at $865 \mathrm{~cm}^{-1}$ is assigned to vibration of $\mathrm{W}-\mathrm{O}-\mathrm{W}$ linkages $[19,20]$. The IR band in the region $460-490 \mathrm{~cm}^{-1}$ is assigned to Te-O-W linkages, which would increase the glass network connectivity and this assignment is made in agreement with the theoretical model for vibrations of mixed bridge bonds containing heavy metal and glass former atoms [21]. The formation of Te-O-W linkages is expected because both $\mathrm{W}$ and Te atoms have comparable electro negativity and can therefore substitute for each other in bonding with $\mathrm{O}$ atoms [21]. That is, there is a fraction of $\mathrm{W}$ cations that have partial covalent bonding and are incorporated in the binary $\mathrm{TeO}_{2}-\mathrm{WO}_{3}$ glass network [17].

Equimolecular substitution of $\mathrm{WO}_{3}$ for $\mathrm{TeO}_{2}$ causes changes in the structure of the $\mathrm{TeO}_{2}-\mathrm{WO}_{3}$ glasses, which is apparent in the IR spectra of glasses (Figure 1). As the $\mathrm{WO}_{3}$ content increases from $10 \mathrm{~mol} \%$ to $40 \mathrm{~mol} \%$, the band at $640 \mathrm{~cm}^{-1}$ in $90 \mathrm{TeO}_{2}-10 \mathrm{WO}_{3}$ (TW1) shifts towards higher wave numbers: from to 640 to 645,665 , and then to $675 \mathrm{~cm}^{-1}$, while the band at $730 \mathrm{~cm}^{-1}$ shifts to $790 \mathrm{~cm}^{-1}$. This observed shift may be due to higher field intensity of 


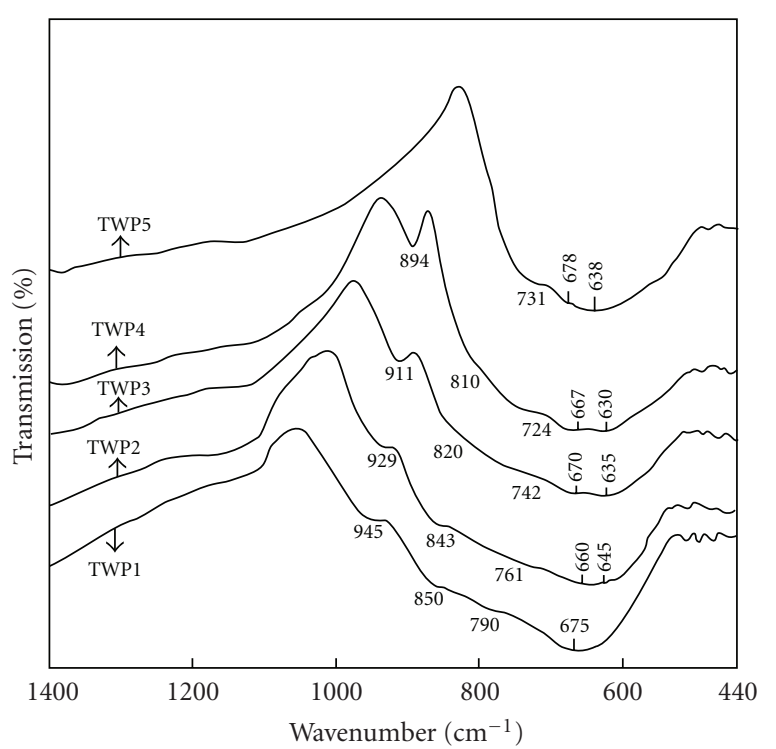

FIgURE 2: IR spectra of $\mathrm{TeO}_{2}-\mathrm{WO}_{3}-\mathrm{PbO}$ glasses.

mixed $\mathrm{Te}-\mathrm{O}-\mathrm{W}$ and $\mathrm{W}-\mathrm{O}-\mathrm{W}$ linkages, in which the oxygen is highly polarized, compared with $\mathrm{Te}-\mathrm{O}-\mathrm{Te}$ linkages, since $\mathrm{W}^{6+}$-ions possess higher field intensity than $\mathrm{Te}^{4+}$-ions [18], and this observed shift may be related to the apparition of $\mathrm{TeO}_{3}$ units concomitant to a reduction in the number of $\mathrm{TeO}_{4}$ units [22]. Thus the effect of addition of $\mathrm{WO}_{3}$ content to the $\mathrm{TeO}_{2}$ glass matrix is to transform the $\mathrm{TeO}_{4}$ basic structural units forming the $\mathrm{TeO}_{2}$ glass to $\mathrm{TeO}_{3}$ units. This is supported by the appearance of IR band in the region 665$680 \mathrm{~cm}^{-1}$ of $70 \mathrm{TeO}_{2}-30 \mathrm{WO}_{3}$ (TW3) and $60 \mathrm{TeO}_{2}-40 \mathrm{WO}_{3}$ (TW4) glass systems corresponding to $\mathrm{TeO}_{3}$ units.

The shoulder at about $850-865 \mathrm{~cm}^{-1}$ relative to the existence of vibration of $\mathrm{W}-\mathrm{O}-\mathrm{W}$ linkages is present for all the glass samples. As the $\mathrm{WO}_{3}$ content increases from 10 to $40 \mathrm{~mol} \%$, this causes a shift in the absorption band at $925 \mathrm{~cm}^{-1}$ due to $\mathrm{WO}_{4}$ units toward higher wave numbers: from 925 to 934,940 , and then to $945 \mathrm{~cm}^{-1}$. The observed shift in the $925 \mathrm{~cm}^{-1}$ band toward higher wave number in the composition range from 10 to $40 \mathrm{~mol} \% \mathrm{WO}_{3}$ is an indication of the transformation of $\mathrm{WO}_{4}$ units to $\mathrm{WO}_{6}$ units. However, the substitution of $\mathrm{TeO}_{2}$ by $\mathrm{WO}_{3}$ causes an increase of networking oxygens, according to the proportion $3 / 2$ and these oxygens form new $\mathrm{Te}-\mathrm{O}-\mathrm{W}$ and $\mathrm{W}-\mathrm{O}-\mathrm{W}$ linkages. Thus the glass network is highly distorted and this suggests the formation of $\mathrm{WO}_{6}$ units at high $\mathrm{WO}_{3}$ content.

3.2. IR Spectra of $60 \mathrm{TeO}_{2}-(40-x) \mathrm{WO}_{3}-x \mathrm{PbO}$ Glasses. The IR spectra of the ternary $\mathrm{TeO}_{2}-\mathrm{WO}_{3}-\mathrm{PbO}$ (TWP) glass system recorded in the wave number region $1400-440 \mathrm{~cm}^{-1}$ are shown in Figure 2. The IR spectra of the glasses are characterized by absorption bands in the wave number regions $890-945 \mathrm{~cm}^{-1}, 810-850 \mathrm{~cm}^{-1}, 724-790 \mathrm{~cm}^{-1}, 600$ $680 \mathrm{~cm}^{-1}$, and $460-490 \mathrm{~cm}^{-1}$. The IR band positions are summarized in Table 3. The band in the region 670$680 \mathrm{~cm}^{-1}$ in $60 \mathrm{TeO}_{2}-40 \mathrm{WO}_{3}$ (TWP1) glass is assigned to
TABLE 3: Observed IR band positions in the $60 \mathrm{TeO}_{2}-(40-\mathrm{x}) \mathrm{WO}_{3}-$ $\mathrm{xPbO}$ glass system.

\begin{tabular}{lllllll}
\hline Sample ID & \multicolumn{7}{c}{ IR bands $\left(\mathrm{cm}^{-1}\right)$} \\
\hline TWP1 & $460-490$ & - & 675 & 790 & 850 & 945 \\
TWP2 & $460-490$ & 645 & 660 & 761 & 843 & 929 \\
TWP3 & $460-490$ & 635 & 670 & 742 & 820 & 911 \\
TWP4 & $460-490$ & 630 & 667 & 724 & 810 & 894 \\
TWP5 & $460-490$ & 638 & 678 & 731 & - & - \\
\hline
\end{tabular}

$\mathrm{TeO}_{3}$ trigonal pyramids, while the band at around 724$790 \mathrm{~cm}^{-1}$ is due to $\mathrm{Te}-\mathrm{O}_{\mathrm{eq}}$ bond vibrations of distorted $\mathrm{TeO}_{4}$ units. The shoulder at $945 \mathrm{~cm}^{-1}$ in TWP1 in the high wave number region of the spectrum is a characteristic of the presence of tungsten ions in $\left[\mathrm{WO}_{6}\right]$ units in the structure of the glass [17]. The shoulder at around $810-850 \mathrm{~cm}^{-1}$ is due to vibration of $\mathrm{W}-\mathrm{O}-\mathrm{W}$ linkages and the band in the region $460-490 \mathrm{~cm}^{-1}$ is assigned to $\mathrm{Te}-\mathrm{O}-\mathrm{W}$ linkages [17]. Equimolecular substitution of $\mathrm{PbO}$ for $\mathrm{WO}_{3}$ causes changes in the structure of the TWP glasses, which is apparent in the IR spectra of glasses (Figure 2).

As the $\mathrm{PbO}$ content increases from 10 to $30 \mathrm{~mol} \%$, this causes a shift in the IR band due to $\mathrm{W}-\mathrm{O}-\mathrm{W}$ linkages towards lower wave numbers: from 850 to 843,820 , and then to $810 \mathrm{~cm}^{-1}$ and also causes a shift in the band $945 \mathrm{~cm}^{-1}$ due to $\mathrm{WO}_{6}$ octahedra toward lower wave numbers: from 945 to 929,911 and then to $894 \mathrm{~cm}^{-1}$. The observed shift in the $945 \mathrm{~cm}^{-1}$ band and in the band $850 \mathrm{~cm}^{-1}$ toward lower wave number in the composition range from 10 to $30 \mathrm{~mol} \% \mathrm{PbO}$ may be an indication of the transformation of $\mathrm{WO}_{6}$ units to $\mathrm{WO}_{4}$ units. This receives support from the appearance of band at $894 \mathrm{~cm}^{-1}$ in $60 \mathrm{TeO}_{2}-30 \mathrm{PbO}-10 \mathrm{WO}_{3}$ (TWP4) and is due to $\mathrm{WO}_{4}$ units [23]. When $\mathrm{WO}_{3}$ is substituted mol by mol by $\mathrm{PbO}$ the number of oxygens in the glass network diminishes according to the ratio $3 / 1$. Thus the glass network becomes less distorted and this also suggests that the formation of $\mathrm{WO}_{4}$ units at high $\mathrm{PbO}$ content. The shoulder at about $850 \mathrm{~cm}^{-1}$ is absent in the IR spectrum of $60 \mathrm{TeO}_{2}-$ $40 \mathrm{PbO}$ glass.

When the $\mathrm{PbO}$ content increases from 10 to $20 \mathrm{~mol} \%$, a new band at around $635 \mathrm{~cm}^{-1}$ is observed in addition to that of $\sim 670 \mathrm{~cm}^{-1}$, which indicates the formation of Te-O$\mathrm{Pb}$ bonds in the glass network and this suggests formation of $\mathrm{TeO}_{4}$ units at the expense of $\mathrm{TeO}_{3}$ units. Thus it is concluded that addition of $\mathrm{PbO}$ causes a change in the coordination state of the tellurium ions and their partial conversion from 3-coordination to 4-coordination. This is supported by the appearance of band in the $600-645 \mathrm{~cm}^{-1}$ region corresponding to $\left[\mathrm{TeO}_{4}\right]$ units. At low proportion of $\mathrm{PbO}$ (up to $20 \mathrm{~mol} \%$ ), it enters the glass network by breaking up the $\mathrm{Te}-\mathrm{O}-\mathrm{Te}, \mathrm{Te}-\mathrm{O}-\mathrm{W}$ bonds and introduces coordination defects known as dangling bond $\left(\mathrm{Te}-\mathrm{O}^{-} \ldots \mathrm{Pb}^{2+} \ldots{ }^{-} \mathrm{O}-\right.$ $\mathrm{Te}$ ) which in turn decreases the $\mathrm{TeO}_{3}$ units by forming $\mathrm{TeO}_{4}$ units [24]. When the PbO content is increased from 20 to $40 \mathrm{~mol} \%$, a considerable proportion may be act as double bridges between adjacent $\mathrm{TeO}_{4}$ and $\mathrm{WO}_{4}$ units such as $=\mathrm{Te}-$ $\mathrm{O}-\mathrm{Pb}-\mathrm{O}-\mathrm{W}=$ which can be formed beside the formation of $\mathrm{PbO}_{4}$ units [25]. The lead in this case acts as a glass forming 


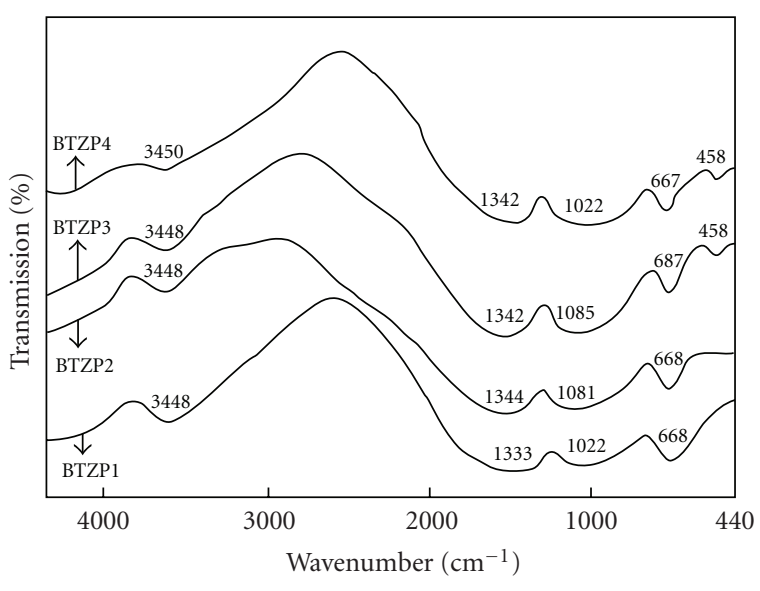

Figure 3: IR spectra of $\mathrm{B}_{2} \mathrm{O}_{3}-\mathrm{TeO}_{2}-\mathrm{ZnO}-\mathrm{PbO}$ glasses.

agent and is incorporated in the glass structure in the form of $\left[\mathrm{PbO}_{4}\right]$ units.

Therefore, for $\mathrm{PbO}$ up to $20-\mathrm{mol} \%$, it plays a network modifier role, and at $x \geq 30$, it plays a network former role in the present system. The study performed clarified the structural species of lead-tungsten tellurite glasses and confirmed the dual structural role of lead ions.

3.3. IR Spectra of $60 \mathrm{~B}_{2} \mathrm{O}_{3}-10 \mathrm{TeO}_{2}-(30-x) \mathrm{ZnO}-x \mathrm{PbO}$ Glasses. The IR spectra of the quaternary $60 \mathrm{~B}_{2} \mathrm{O}_{3}-10 \mathrm{TeO}_{2}-(30-$ $\mathrm{x}) \mathrm{ZnO}-\mathrm{xPbO}$ (BTZP) glass system recorded in the wave number region $4000-440 \mathrm{~cm}^{-1}$ are shown in Figure 3. The IR spectra of these glasses are characterized by absorption bands in the wave number regions $3436-3450 \mathrm{~cm}^{-1}, 1333-$ $1390 \mathrm{~cm}^{-1}, 950-1085 \mathrm{~cm}^{-1}, 665-687 \mathrm{~cm}^{-1}$, and $458 \mathrm{~cm}^{-1}$. The IR band positions of the present glass system are summarized in Table 4.

The IR band absorption in the high wave number region of the spectrum with maximum in the 3436$3450 \mathrm{~cm}^{-1}$ region belongs to $\mathrm{O}-\mathrm{H}$ stretching vibrations [26]. In the present glass system (BTZP), the disappearance of the absorption band at $806 \mathrm{~cm}^{-1}$ indicates the absence of boroxol ring formation and thus clearly indicating the presence of triborate $\left[\mathrm{BO}_{3}\right]$ and tetra borate $\left[\mathrm{BO}_{4}\right]$ units. The IR absorption band in the $950-1085 \mathrm{~cm}^{-1}$ in all the glasses is due to stretching vibrations of $\mathrm{B}-\mathrm{O}$ bond of $\left[\mathrm{BO}_{4}\right]$ units $[27,28]$ and the absorption band in the $1333-1390 \mathrm{~cm}^{-1}$ region can be attributed to stretching vibrations of $\mathrm{B}-\mathrm{O}$ bond of $\left[\mathrm{BO}_{3}\right]$ units [29].

The absorption band at around $668 \mathrm{~cm}^{-1}$ indicates the presence of tellurium-oxygen groups. The structure pattern of tellurium-containing glasses is determined by trigonal pyramids $\left[\mathrm{TeO}_{3}\right]$ and trigonal bipyramids $\left[\mathrm{TeO}_{4}\right]$. The absorption in the range of $600-700 \mathrm{~cm}^{-1}$ in such glasses is determined by the stretching vibrations of $\mathrm{Te}-\mathrm{O}$ bonds in $\left[\mathrm{TeO}_{3}\right]$ and $\left[\mathrm{TeO}_{4}\right]$ units. The absorption of $\left[\mathrm{TeO}_{3}\right]$ units has a high-wave number position than $\left[\mathrm{TeO}_{4}\right]$ units. In general case, the absorption band range of $\left[\mathrm{TeO}_{3}\right]$ units correlates with $650-700 \mathrm{~cm}^{-1}$ and that of $\left[\mathrm{TeO}_{4}\right]$ units correlates with $600-650 \mathrm{~cm}^{-1}[14,30]$. Analyzing the obtained results and
TABLE 4: Observed IR band positions in the $60 \mathrm{~B}_{2} \mathrm{O}_{3}-10 \mathrm{TeO}_{2}-(30$ $\mathrm{x}) \mathrm{ZnO}-\mathrm{xPbO}$ glass system.

\begin{tabular}{lccccc}
\hline Sample ID & \multicolumn{5}{c}{ IR bands $\left(\mathrm{cm}^{-1}\right)$} \\
\hline BTZP1 & - & 668 & 1022 & 1333 & 3448 \\
BTZP2 & - & 668 & 1081 & 1344 & 3448 \\
BTZP3 & 458 & 687 & 1085 & 1342 & 3448 \\
BTZP4 & 458 & 667 & 1022 & 1342 & 3450 \\
\hline
\end{tabular}

comparing them to the published data [12], it is clear that trigonal pyramids $\left[\mathrm{TeO}_{3}\right]$ are present in the structure of all the glass systems (BTZP) because the absorption band appears at $667-685 \mathrm{~cm}^{-1}$ region. For lower concentration of $\mathrm{PbO}$ (20 mol\%), $\mathrm{PbO}$ substituted for $\mathrm{ZnO}$ in BTZP series causes changes in the structure of the glasses, which is apparent in a shift of the absorption band at $668 \mathrm{~cm}^{-1}$ to higher wave number side up to $687 \mathrm{~cm}^{-1}$. Usually a shift of absorption bands to higher wave numbers occurs as a result of an increase in the degree of polymerization of the structural network $\left[\mathrm{TeO}_{3}\right]$ units of the glass system. Absorption band at $687 \mathrm{~cm}^{-1}$ shifted to the lower wave number side, as the mole percentage of $\mathrm{PbO}$ increased from 20 to 30. These changes are may be due to formation of Te$\mathrm{O}-\mathrm{Pb}$ linkages and dual role of lead ions in the glass network.

In Figure 3, the band around $1022 \mathrm{~cm}^{-1}$ in BTZP1 shifts up to $1085 \mathrm{~cm}^{-1}$ as the content of $\mathrm{PbO}$ increases up to $20 \mathrm{~mol} \%$ and the band around $1085 \mathrm{~cm}^{-1}$ shifts up to $1022 \mathrm{~cm}^{-1}$ as the content of $\mathrm{PbO}$ increases from 20 to $30 \mathrm{~mol} \%$. In lead borate glasses [31], at low concentrations (15-20 mol\%) PbO acts as a modifier of the structural network in the form of $\left[\mathrm{PbO}_{6}\right]$ groups and promotes conversion of $\left[\mathrm{BO}_{3}\right]$ units to $\left[\mathrm{BO}_{4}\right]$ tetrahedra. Above $15-$ $20 \mathrm{~mol} \% \mathrm{PbO}$, some lead ions enter the structure as network former in the form of $\left[\mathrm{PbO}_{4}\right]$ units. The absorption band at $458 \mathrm{~cm}^{-1}$ in BTZP3 and BTZP4 probably belongs to the $\mathrm{Pb}$ $\mathrm{O}$ vibration of $\left[\mathrm{PbO}_{4}\right]$ units [32]. Thus the fraction of $\left[\mathrm{BO}_{4}\right]$ units increases as the content of $\mathrm{PbO}$ increases from 20 to $30 \mathrm{~mol} \%$. It is clear from Figure 3 that there is no significant change in position but there is clear evidence of a decrease in the intensity of the absorption band around $1342 \mathrm{~cm}^{-1}$, and a corresponding increase in the intensity of the band at $1022 \mathrm{~cm}^{-1}$ is observed in the spectra of all the glasses in BTZP series. This observation suggests that the number of $\left[\mathrm{BO}_{3}\right]$ units decreases and the fraction of $\left[\mathrm{BO}_{4}\right]$ units increases as the $\mathrm{PbO}$ content increases. The study performed clarified the structural species of $\mathrm{B}_{2} \mathrm{O}_{3}-\mathrm{TeO}_{2}-\mathrm{ZnO}-\mathrm{PbO}$ glasses and confirmed the dual structural role of lead ions.

\section{Conclusions}

Transparent and stable glasses were obtained in the $\mathrm{TeO}_{2}-$ $\mathrm{WO}_{3}, \mathrm{TeO}_{2}-\mathrm{WO}_{3}-\mathrm{PbO}$, and $\mathrm{B}_{2} \mathrm{O}_{3}-\mathrm{TeO}_{2}-\mathrm{ZnO}-\mathrm{PbO}$ glass systems. The IR results show the progressive transformation of the $\mathrm{TeO}_{4}$ units to more distorted $\mathrm{TeO}_{3+1}$ units for $\mathrm{TeO}_{2}-$ $\mathrm{WO}_{3}$ glasses with increasing $\mathrm{WO}_{3}$ content. Addition of $\mathrm{PbO}$ and $\mathrm{WO}_{3}$ increases the population of lower coordination units $\left[\mathrm{TeO}_{3}\right] /\left[\mathrm{TeO}_{3+1}\right]$ in the $\mathrm{TeO}_{2}-\mathrm{WO}_{3}-\mathrm{PbO}$ glass network at the expense of higher coordination units $\left[\mathrm{TeO}_{4}\right]$. Addition 
of $\mathrm{WO}_{3}$ to the glass systems of $\mathrm{TeO}_{2}-\mathrm{WO}_{3}$ and $\mathrm{TeO}_{2}-\mathrm{WO}_{3}-$ $\mathrm{PbO}$ results in the formation of more $\mathrm{W}-\mathrm{O}-\mathrm{W}$ and $\mathrm{W}-\mathrm{O}-$ $\mathrm{Te}$ linkages, while that of the $\mathrm{Te}-\mathrm{O}-\mathrm{Te}$ linkages decreases as $\mathrm{WO}_{3}$ increases. In the case of $\mathrm{TeO}_{2}-\mathrm{WO}_{3}-\mathrm{PbO}$ glasses, the $\mathrm{TeO}_{3} / \mathrm{TeO}_{3+1}$ units are transformed to $\mathrm{TeO}_{4}$ units with increasing $\mathrm{PbO}$ content. Increasing the $\mathrm{PbO}$ content in $\mathrm{B}_{2} \mathrm{O}_{3}-\mathrm{TeO}_{2}-\mathrm{ZnO}-\mathrm{PbO}$ glasses causes partial conversion of the boron ions from trigonal coordination $\left[\mathrm{BO}_{3}\right]$ to $\left[\mathrm{BO}_{4}\right]$ tetrahedral coordination. $\left[\mathrm{TeO}_{3}\right]$ units are present in all the glass samples of $\mathrm{B}_{2} \mathrm{O}_{3}-\mathrm{TeO}_{2}-\mathrm{ZnO}-\mathrm{PbO}$ glass system and the dual role of the lead ions is confirmed in this glass system.

\section{Acknowledgment}

G. Upender is grateful to UGC (University Grants Commission), New Delhi, for providing financial assistance under the scheme of RFSMS (Research Fellowships in Science for Meritorious Students).

\section{References}

[1] P. Marcel, Annales de Chimie, Science des Matériaux, vol. 28, p. 87, 2003.

[2] M. J. Weber, J. D. Myers, and D. H. Blackburn, "Optical properties of $\mathrm{Nd}^{3+}$ in tellurite and phosphotellurite glasses," Journal of Applied Physics, vol. 52, no. 4, pp. 2944-2949, 1981.

[3] K. Shioya, T. Komatsu, H. G. Kim, R. Sato, and K. Matusita, "Optical properties of transparent glass-ceramics in $\mathrm{K}_{2} \mathrm{ONb}_{2} \mathrm{O}_{5} \mathrm{TeO}_{2}$ glasses," Journal of Non-Crystalline Solids, vol. 189, no. 1-2, pp. 16-24, 1995.

[4] R. A. F. El-Mallawany, Tellurite Glasses Handbook-Physical Properties and Data, CRC Press, Boca Raton, Calif, USA, 2001.

[5] T. Kosuge, Y. Benino, V. Dimitrov, R. Sato, and T. Komatsu, "Thermal stability and heat capacity changes at the glass transition in $\mathrm{K}_{2} \mathrm{O}-\mathrm{WO}_{3}-\mathrm{TeO}_{2}$ glasses," Journal of Non-Crystalline Solids, vol. 242, no. 2-3, pp. 154-164, 1998.

[6] I. Shaltout, Y. Tang, R. Braunstein, and E. E. Shaisha, "FTIR spectra and some optical properties of tungstate-tellurite glasses," Journal of Physics and Chemistry of Solids, vol. 57, no. 9, pp. 1223-1230, 1996.

[7] R. A. F. El-Mallawany, Tellurite Glasses Handbook, CRC Press, Boca Raton, Calif, USA, 2002.

[8] E. Fargin, A. Berthereau, T. Cardinal, et al., "Optical nonlinearity in oxide glasses," Journal of Non-Crystalline Solids, vol. 203, pp. 96-101, 1996.

[9] B. N. Meera, A. K. Sood, N. Chandrabhas, and J. Ramakrishna, "Raman study of lead borate glasses," Journal of NonCrystalline Solids, vol. 126, no. 3, pp. 224-230, 1990.

[10] T. Takaishi, M. Takahashi, J. Jin, T. Uchino, T. Yoko, and M. Takahashi, "Structural study on $\mathrm{PbO}-\mathrm{SiO}_{2}$ glasses by X-ray and neutron diffraction and ${ }^{29}$ Si MAS NMR measurements," Journal of the American Ceramic Society, vol. 88, no. 6, pp. 1591-1596, 2005.

[11] K. J. Rao, B. G. Rao, and S. R. Elliott, "Glass formation in the system $\mathrm{PbO}-\mathrm{PbCI}_{2}$," Journal of Materials Science, vol. 20, no. 5, pp. 1678-1682, 1985.

[12] G. E. Rachkovskaya and G. B. Zakharevich, "IR spectra of tellurium germanate glasses and their structure," Journal of Applied Spectroscopy, vol. 74, no. 1, pp. 86-89, 2007.
[13] L. M. Fortes, L. F. Santos, M. C. Goncalves, and R. M. Almeida, "Preparation and characterization of $\mathrm{Er}^{3+}$-doped $\mathrm{TeO}_{2}$-based oxyhalide glasses," Journal of Non-Crystalline Solids, vol. 324, no. 1-2, pp. 150-158, 2003.

[14] Y. Dimitriev, V. Dimitrov, and M. Arnaudov, "IR spectra and structures of tellurite glasses," Journal of Materials Science, vol. 18, no. 5, pp. 1353-1358, 1983.

[15] V. Dimitrov, M. Arnaudov, and Y. Dimitriev, "IR-spectral study of the effect of $\mathrm{WO}_{3}$ on the structure of tellurite glasses," Monatshefte für Chemie, vol. 115, no. 8-9, pp. 987-991, 1984.

[16] P. Caillet and P. Saumagne, "Étude des monomolybdates et monowolframates alcalins anhydres par spectroscopie infrarouge et raman," Journal of Molecular Structure, vol. 4, no. 2-4, pp. 191-201, 1969.

[17] P. Charton, L. Gengembre, and P. Armand, " $\mathrm{TeO}_{2}-\mathrm{WO}_{3}$ glasses: infrared, XPS and XANES structural characterizations," Journal of Solid State Chemistry, vol. 168, no. 1, pp. 175183, 2002.

[18] D. Munoz-Martín, M. A. Villegas, J. Gonzalo, and J. M. Fernández-Navarro, "Characterisation of glasses in the $\mathrm{TeO}_{2}$ $\mathrm{WO}_{3}$-PbO system," Journal of the European Ceramic Society, vol. 29, no. 14, pp. 2903-2913, 2009.

[19] M. Tatsumisago, T. Minami, Y. Kowada, and H. Adachi, "Structural change of rapidly quenched binary tellurite glasses with composition and temperature," Physics and Chemistry of Glasses, vol. 35, no. 2, pp. 89-97, 1994.

[20] S. Muthupari and K. J. Rao, "Thermal and infrared spectroscopic studies of binary $\mathrm{MO}_{3}-\mathrm{P}_{2} \mathrm{O}_{5}$ and ternary $\mathrm{Na}_{2} \mathrm{O}$ $\mathrm{MO}_{3}-\mathrm{P}_{2} \mathrm{O}_{5}(M=M o$ or $W)$ glasses," Journal of Physics and Chemistry of Solids, vol. 57, no. 5, pp. 553-561, 1996.

[21] I. Shaltout, Y. Tang, R. Braunstein, and A. M. Abu-Elazm, "Structural studies of tungstate-tellurite glasses by raman spectroscopy and differential scanning calorimetry," Journal of Physics and Chemistry of Solids, vol. 56, no. 1, pp. 141-150, 1995.

[22] Y. Mizuno, M. Ikeda, and A. Yoshida, "Application of tellurite bonding glasses to magnetic heads," Journal of Materials Science Letters, vol. 11, no. 24, pp. 1653-1656, 1992.

[23] C. Y. Wang, Z. X. Shen, and B. V. R. Chowdari, "Raman studies of $\mathrm{Ag}_{2} \mathrm{O} \cdot \mathrm{WO}_{3} \cdot \mathrm{TeO}_{2}$ ternary glasses," Journal of Raman Spectroscopy, vol. 29, no. 9, pp. 819-823, 1998.

[24] D. Lezal, J. Horak, J. Navratil, S. Karamazov, and A. Sklenar, "Reflectivity spectra of $\mathrm{PbO}-\mathrm{TeO}_{2}-\mathrm{SiO}_{2}$ glasses with high $\mathrm{PbO}$ content," Physics and Chemistry of Glasses, vol. 42, no. 4-5, pp. 324-327, 2001.

[25] V. R. Kumar and N. Veeraiah, "Dielectric properties of $\mathrm{ZnF}_{2}$ $\mathrm{PbO}-\mathrm{TeO}_{2}$ glasses," Journal of Physics and Chemistry of Solids, vol. 59, no. 1, pp. 91-97, 1998.

[26] P. J. Bray and J. G. Okeese, Interaction of Radiation with Solids, Dienum, New York, NY, USA, 1967.

[27] E. I. Kamitsos, M. A. Karakassides, and G. D. Chryssikos, "A vibrational study of lithium sulfate based fast ionic conducting borate glasses," Journal of Physical Chemistry, vol. 90, no. 19, pp. 4528-4533, 1986.

[28] M. Ganguli and K.J. Rao, "Studies on the effect of $\mathrm{Li}_{2} \mathrm{SO}_{4}$ on the structure of lithium borate glasses," Journal of Physical Chemistry B, vol. 103, no. 6, pp. 920-930, 1999.

[29] E. I. Kamitsos, A. P. Patsis, M. A. Karakassides, and G. D. Chryssikos, "Infrared reflectance spectra of lithium borate glasses," Journal of Non-Crystalline Solids, vol. 126, no. 1-2, pp. 52-67, 1990. 
[30] A. G. Vlasov and V. A. Florinski, Eds., Structure and Physicochemical Properties of Inorganic Glasses, Leningrad, Khimiya, Russia, 1974.

[31] N. M. Pavlushkin and A. K. Zhuravlev, Low-Melting Glasses, Energiya, Moscow, Russia, 1970.

[32] G. Srinivasarao and N. Veeraiah, "Influence of $\mathrm{Cr}^{3+}$ ions on the structure and certain physical properties of $\mathrm{PbO}-\mathrm{As}_{2} \mathrm{O}_{3}$ glasses," The European Physical Journal-Applied Physics, vol. 16, no. 1, pp. 11-22, 2001. 